\title{
MIKROENKAPSULASI MINYAK ASIRI JERUK NIPIS DENGAN KOASERVASI KOMPLEKS YANG BERAKTIVITAS ANTIBAKTERI UNTUK APLIKASI PADA BAHAN TEKSTIL
}

\author{
MICROENCAPSULATION OF LIME ESSENTIAL OIL BY COMPLEX \\ COACERVATION WITH ANTIBACTERIAL ACTIVITY FOR APPLICATIONS IN \\ TEXTILE FABRIC
}

\author{
Euis Julaeha, ${ }^{1}$ Sandra Puspita, ${ }^{1}$ Tatang Wahyudi, ${ }^{2}$ Jakariya Nugraha, ${ }^{2}$ Diana Rakhmawaty Eddy ${ }^{1}$ \\ ${ }^{1}$ Departemen Kimia, Fakultas Matematika dan ilmu Pengetahuan Alam, Universitas Padjadjaran, Sumedang \\ ${ }^{2}$ Balai Besar Tekstil, Jl. Jendral Ahmad Yani No. 390, Bandung \\ E-mail:kimia@unpad.ac.id
}

Tanggal diterima: 5 November 2020, direvisi: 16 Desember 2020, disetujui terbit: 17 Desember 2020

\begin{abstract}
ABSTRAK
Imobilisasi mikrokapsul minyak asiri jeruk nipis pada kain kapas telah dilakukan dengan metode pad dry cure menggunakan binder asam sitrat 3\%. Minyak asiri dipreparasi menggunakan metode hidrodestilasi. Mikrokapsul berisi zat aktif alami minyak asiri jeruk nipis (C. aurantifolia) yang dibuat dengan metode koaservasi kompleks menggunakan penyalut alginat dan gelatin, pengikat silang glutaraldehid, dan pengemulsi polysorbate. Aktivitas antibakteri mikrokapsul sebelum diimobilisasi dan setelah diimobilisasi dilakukan terhadap bakteri Staphylococcus aureus, Staphylococcus epidermidis, Escherichia coli, dan Klebsiella pneumoniae, dengan metode Kirby Bauer. Mikrokapsul dikarakterisasi dengan Particle Size Analyzer (PSA), Spektroskopi UV-Vis, dan Scanning Electron Microscopy (SEM). Hasil hidrodestilasi diperoleh rendemen minyak asiri sebesar 1,10\%, berwarna kuning pucat, beraroma segar khas jeruk nipis. Hasil preparasi mikrokapsul diperoleh rendemen sebesar 46,28\%; distribusi ukuran partikel homogen dengan ukuran pada rentang 1,604 $\mu \mathrm{m}$; kandungan minyak 61,89\%; efisiensi enkapsulasi 87,37\%; dengan morfologi berbentuk bulat dengan permukaan halus. Kain yang telah diimobilisasi memiliki ketahanan cuci yang baik. Kain kapas tersebut dapat menghambat keempat bakteri S. aureus, S. epidermidis, E. coli, dan K. pneumoniae dengan daya hambat rata-rata berturut turut sebesar $12,08 \pm 0,13$; $8,90 \pm 0,10 ; 10,83 \pm 0,43$; dan $10,40 \pm 0,10$.
\end{abstract}

Kata kunci: mikroenkapsulasi, minyak asiri, jeruk nipis, koaservasi kompleks, antibakteri

\section{ABSTRACT}

Microcapsule immobilization of lime essential oil on cotton fabric was performed using the pad dry cure method using 3\% citric acid binder. The essential oils were prepared using the hydrodistillation method. Microcapsules contained natural active substances of lime essential oil (C. aurantifolia) which are made by a complex coacervation method using alginate and gelatin coatings, glutaraldehyde crosslinkers, and polysorbate emulsifiers. Antibacterial activity before immobilization and after immobilization was carried out against Staphylococcus aureus bacteria, Staphylococcus epidermidis, Escherichia coli, and Klebsiella pneumoniae, using the Kirby Bauer method. Microcapsules were characterized by Particle Size Analyzer (PSA), UV-Vis Spectroscopy, and Scanning Electron Microscopy (SEM). The result of hydrodistillation showed that the essential oil yield was $1.10 \%$, pale yellow in color and had a distinctive fresh aroma of lime. The results of microcapsule preparation obtained a yield of $46.28 \%$; homogeneous particle size distribution with sizes in the range of $1.604 \mu \mathrm{m}$; oil content 61.89\%; encapsulation efficiency $87.37 \%$; with a spherical morphology with a smooth surface. Immobilized fabrics had good washing durability. The cotton fabric showed inhibition activity against four bacteria S. aureus, S. epidermidis, E. coli, and K. pneumoniae with an average inhibition power of $12.08 \pm 0.13 ; 8.90 \pm 0.10 ; 10.83 \pm 0.43$; and $10.40 \pm 0.10$.

Keywords: microencapsulation, essential oil, lime, complex coacervation, antibacterial

\section{PENDAHULUAN}

Jeruk nipis (Citrus aurantifolia) adalah tanaman yang tumbuh subur di daerah beriklim tropis. Jenis jeruk ini banyak digunakan di industri olahan makanan dan minuman, karena selain rasanya yang enak dan segar juga memiliki kandungan nutrisi dan vitamin $C$ yang tinggi yang baik untuk kesehatan. Di industri pengolahan minuman dan makanan yang menggunakan bahan baku buah jeruk nipis, umumnya yang 
dimanfaatkan hanya bagian daging buahnya saja, bagian kulit buahnya dibuang menjadi limbah. Padahal pada kulit jeruk nipis terkandung suatu minyak asiri yang diketahui memiliki berbagai aktivitas farmakologi, diantaranya sebagai antibakteri, antijamur, antikanker, antifertilitas, antiobesitas, dan aktivitas kardiovaskular. ${ }^{1,4}$ Minyak asiri jeruk nipis juga digunakan sebagai disinfeksi, zat antiinflamasi, relaksasi, stimulasi, antioksidan, antidepresan, antijamur, dan antikarsinogenik, dalam pengobatan klinis. ${ }^{3,4}$ Selain itu, minyak asiri kulit jeruk nipis telah terbukti menunjukkan aktivitas antimikotik, antivirus, antitoksigenik, antiparasit, dan insektisida. ${ }^{5}$

Aktivitas dari minyak asiri ini tidak terlepas dari peranan komponen kimia yang terkandung di dalamnya. Komponen utama minyak asiri jeruk nipis adalah limonen, $\alpha$-terpineol, terpinen-4-ol, dan $\beta$-pinen ${ }^{6}$. Sifat antibakteri minyak asiri dilaporkan karena adanya kandungan limonen yang merupakan kelompok senyawa terpenoid. ${ }^{7,8}$

Dalam pemanfaatan minyak asiri ini mengalami keterbatasan karena sifatnya yang mudah menguap dan tidak stabil terhadap oksigen, panas, atau cahaya. ${ }^{9}$ Oleh karena itu, diperlukan suatu teknik pengemasan minyak asiri untuk menutupi kelemahan tersebut. Teknologi mikroenkapsulasi dilaporkan dapat mengurangi kelemahan minyak asiri. Teknologi ini banyak digunakan pada berbagai bidang seperti kesehatan, kosmetik, farmasi, tekstil, dan agrikultur. ${ }^{10}$

Adamiec et al. ${ }^{11}$ telah membuat mikrokapsul minyak asiri jeruk nipis kaffir dengan penyalut konjac glukomanan dan gum Arabic, yang diujikan pada bakteri uji S. aureus, Salmonella typimurium, E. coli, Vibrio cholerae, dan Pseudomonas Fluorescens. Kumari et al., ${ }^{12}$ membuat fragrant textiles yang mengandung mikrokapsul minyak asiri jeruk nipis menggunakan penyalut gum acacia dan gelatin. Sharkawy et al. ${ }^{13}$ membuat mikrokapsul yang berisi limonen dan vanillin dengan penyalut kitosan dan gum arab yang disisipkan pada kain kapas, dan diujikan pada bakteri $S$. aureus dan $E$. coli. Wijesirigunawardana \& Perera $^{14}$ membuat mikrokapsul minyak asiri kulit jeruk nipis, penyalut kitosan dan gom arab yang disisipkan pada kain kapas dengan binder asam suksinat dan diujikan pada bakteri S. aureus, E. coli, Bacillus cereus, Salmonella typhimurium. Imobilisasi mikrokapsul minyak asiri jeruk nipis dengan penyalut alginatgelatin pada kain kapas dengan binder asam sitrat belum ada yang melakukan. Pada penelitian ini sebelumnya telah dilakukan mikroenkapsulasi dengan metode koaservasi kompleks menggunakan penyalut alginat dan gelatin, pengikat silang glutaraldehid, pengemulsi polysorbate, ${ }^{15}$ namun belum diaplikasikan pada kain.

Artikel ini melaporkan imobilisasi mikrokapsul yang berisi minyak asiri jeruk nipis pada serat kain kapas dengan binder asam sitrat. Pada mikroenkapsulasi digunakan metode koaservasi kompleks menggunakan penyalut biopolimer yang bersifat ramah lingkungan yaitu gelatin dan alginat, pengikat silang glutaraldehid, dan pengemulsi polysorbate. Bakteri uji yang digunakan adalah bakteri yang banyak ditemukan pada kulit yaitu $S$. aureus, E. coli, K. pneumoniae, dan S. epidermidis.

\section{METODE \\ Bahan}

Jeruk nipis diperoleh dari Pasar Induk Caringin, Bandung. Gelatin, natrium alginat, dan polioksietilen sorbitan monooleate/polysorbate $\left(\mathrm{C}_{64} \mathrm{H}_{124} \mathrm{O}_{26}\right)$ diperoleh dari PT. Subur Jaya Kimia, Bandung. Glutaraldehid, aseton, natrium sulfat anhidrat, asam asetat glasial, $n$-heksana, asam sitrat, dan natrium dihidrogen fosfat dihidrat seluruhnya diperoleh dari Merck. Akuades, kain kapas 100\% diperoleh dari Balai Besar Tekstil, Bandung, dengan spesifikasi seperti tercantum pada Tabel 1.

Tabel 1. Spesifikasi kain kapas

\begin{tabular}{ll}
\hline Parameter & $\begin{array}{l}\text { Relevant } \\
\text { Value }\end{array}$ \\
\hline Berat & $117,3 \mathrm{~g} / \mathrm{m}^{2}$ \\
Tetal benang lusi & 84 helai/inci \\
Tetal benang pakan & 66 helai/inci \\
No. benang lusi dan pakan & $\mathrm{Ne}_{1} 321$ \\
Komposisi & $100 \%$ kapas \\
Anyaman & Polos $1 / 1$ \\
\hline
\end{tabular}

\section{Preparasi Minyak Asiri}

Preparasi minyak asiri jeruk nipis mengikuti prosedur yang telah dilakukan Julaeha et al., ${ }^{10}$ yaitu sebagai berikut: kulit jeruk yang sudah bersih dipotong-potong dimasukkan ke dalam labu distilasi, kemudian direndam dengan akuades. Selanjutnya dihidrodistilasi selama 3 jam. Distilat minyak asiri dipisahkan dari lapisan air, kemudian diberi $\mathrm{NaSO}_{4}$ anhidrat. Pengerjaan ini diulang sampai mendapatkan jumlah yang diperlukan.

\section{Mikroenkapsulasi}

Pembuatan mikroenkapsulasi dilakukan dengan metode koaservasi kompleks dengan tahapan sebagai berikut: Setiap larutan polimer disiapkan dalam akuades. Gelatin sebanyak 2,8 g dilarutkan ke dalam akuades sebanyak $140 \mathrm{~mL}$ diaduk dengan magnetic stirrer pada suhu $60 \pm 1^{\circ} \mathrm{C}$ dan laju pengadukan $600 \mathrm{rpm}$. Selanjutnya, polysorbate ditambahkan ke dalam larutan tersebut sebanyak 0,8 g dan minyak asiri $2 \mathrm{~g}$ dimasukkan ke dalam larutan. Setelah penambahan minyak, ditambahkan larutan natrium alginat $(0,8 \mathrm{~g}$ dalam $40 \mathrm{~mL}$ akuades) tetes demi tetes. Setelah itu, gelas kimia yang berisi larutan diaduk selama 15 menit 
pada suhu $60^{\circ} \mathrm{C}$. pH campuran kemudian diturunkan menjadi 3,75 dengan menambahkan $2,5 \%(\mathrm{v} / \mathrm{v})$ larutan asam asetat glasial. Larutan didinginkan pada suhu $5-10^{\circ} \mathrm{C}$. Mikrokapsul yang terbentuk dalam larutan tersebut ditambahkan glutaraldehid $(0,183 \mathrm{~g})$ secara perlahan. Suhu larutan tersebut dinaikkan menjadi $35^{\circ} \mathrm{C}$ dan pengadukan dilanjutkan selama 3-4 jam lagi untuk menyelesaikan reaksi pengikatan silang. Larutan kemudian didinginkan sambil diaduk sampai suhu kamar. Mikrokapsul disaring dan dicuci dengan air. Mikrokapsul selanjutnya dicuci lebih cepat dengan $n$-heksana untuk menghilangkan minyak yang menempel pada permukaan mikrokapsul. Mikrokapsul dikeringkan dan dibekukan dalam lemari es.

\section{Karakterisasi Mikrokapsul}

a. Pengukuran Kandungan Minyak Asiri

Pengujian kandungan minyak asiri dalam mikrokapsul dilakukan dengan menggunakan alat UV-Vis spektrometer brand Perkin-Elmer with Lambda 35 type. Pertama-tama dibuatkan kurva baku minyak asiri dalam pelarut $n$ heksana pada $\lambda 230 \mathrm{~nm}$. Mikrokapsul digerus dengan mortir dan ditambahkan pelarut $n$ heksana $(5 \mathrm{~mL})$ untuk melarutkan minyak asiri yang terkandung dalam mikrokapsul, kemudian diukur absorbannya. Kandungan minyak asiri dalam mikrokapsul dan efisiensi enkapsulasi dihitung dengan persamaan (1) dan (2):

$$
\begin{aligned}
& \text { Oil content }(\%)=\frac{w 1}{w} \times 100 \% \\
& E E(\%)=\frac{w 1}{w 2} \times 100 \%
\end{aligned}
$$

dimana, $\mathrm{w}=$ berat mikrokapsul, $\mathrm{w} 1=$ banyaknya minyak asiri yang tersalut, dan $\mathrm{w} 2$ = banyaknya minyak asiri yang ditambahkan.

b. Release oil (pelepasan minyak asiri)

Studi release oil dari mikrokapsul menggunakan spektrofotometer UV-vis. Sejumlah mikrokapsul ditempatkan dalam $n$-heksana dengan volume yang diketahui. Campuran tersebut diaduk dari waktu ke waktu dengan kecepatan pengadukan $100 \mathrm{rpm}$ pada suhu ruang. Sampel diujikan dengan spektrofotometer UV-vis pada $\lambda 230 \mathrm{~nm}$.

c. Pengukuran Ukuran Partikel

Pengukuran ukuran partikel dilakukan dengan alat PSA Beckman Coulter LS 13 320, equipped with optical Fraunhofer, dengan cairan pembawa air.

d. Pengukuran Morfologi dengan Scanning Electron Microscope (SEM)

Pengukuran morfologi menggunakan alat SEM JEOL JSM-6510 dengan perbesaran 500x, 1000x dan 1500x, aliran listrik $10 \mathrm{kV}$ dan detektor BEI (Backscatter Electron Image).

\section{Imobilisasi Mikrokapsul pada Kain Kapas}

Immobilisasi mikrokapsul pada kain kapas diawali dengan penyiapan sampel kain kapas siap celup berukuran $30 \mathrm{~cm} \quad$ x $40 \mathrm{~cm}$, larutan mikrokapsul, asam sitrat (binder), dan katalis. Volume larutan dibuat $100 \mathrm{~mL}$ dengan masingmasing kadar sebagai berikut: mikrokapsul 20\%, asam sitrat 3\%, katalis natrium sulfat anhidrat $1,5 \%$, dan polysorbate $(0,8 \mathrm{~g})$. Larutan diaduk sampai homogen, kemudian kain dimasukkan ke dalam larutan mikrokapsul selama 5-10 menit sambil diaduk. Sampel kain selanjutnya diperas dengan padder (Werner Mathis AG) kemudian dikeringkan pada mesin Curing HT Steam (Werner Mathis AG) selama 2 menit pada suhu $100^{\circ} \mathrm{C}$ dan curing di mesin yang sama pada suhu $130^{\circ} \mathrm{C}$ selama 2 menit. Sampel kain yang telah mengalami perlakuan dengan mikrokapsul dihitung $\%$ add-on (penambahan beratnya), diamati menggunakan SEM, diuji daya tahan cucinya dengan Launder-Ometer sesuai standar uji SNI ISO 105-C06:2010, dan diuji aktivitas antibakterinya. Penambahan berat dari kain setelah di-treatment dapat dihitung menggunakan persamaan (3):

Add on $(\%)=\frac{w a-w b}{w b} \times 100 \%$

dimana, wa = berat setelah dilakukan treatment dan $\mathrm{wb}=$ berat sebelum dilakukan treatment

\section{Aktivitas Antibakteri}

Uji aktivitas antibakteri dari minyak asiri, limonen, dan kain menggunakan metode Kirby bauer terhadap bakteri Gram positif Staphylococcus aureus (ATCC 6538); Staphylococcus epidermidis (ATCC 11228); dan bakteri Gram negatif Escherichia coli (ATCC 11229); Klebsiella pneumoniae (ATCC 2357). Strain mikroba dikulturkan semalam sekitar $10^{5} \mathrm{CFU} / \mathrm{mL}$ dengan larutan garam steril. Suspensi sebanyak $500 \mu \mathrm{L}$ diletakkan di atas media agar yang berisi MHA (untuk bakteri Gram positif) dan NA (untuk bakteri Gram negatif). Cakram kosong steril diresapi dengan $20 \mu \mathrm{L}$ minyak asiri/cakram digantikan dengan kain yang telah diimobilisasi mikrokapsul dan ditempatkan di atas permukaan. Ampicillin (1000 ppm/cakram) digunakan sebagai kontrol positif. Pelat diinkubasi pada suhu $37^{\circ} \mathrm{C}$ selama 24 jam. Aktivitas antimikroba diukur berdasarkan zona penghambatan (mm).

\section{HASIL DAN PEMBAHASAN Hasil preparasi minyak asiri}

Preparasi minyak asiri jeruk nipis dilakukan dengan teknik hidrodistilasi. Teknik ini banyak digunakan untuk mengekstraksi minyak asiri karena memiliki rendemen yang tinggi. ${ }^{17}$ Dari $11,9 \mathrm{~kg}$ kulit jeruk nipis diperoleh minyak asiri sebanyak $131 \mathrm{~g}$, sehingga didapatkan rendemen sebesar $1,10 \%$. 
Umumnya rendemen minyak asiri berkisar antara $0,30-1,00 \%^{18}$ dan $0,21-2,30 \%, 4,9$ sehingga rendemen yang diperoleh sudah termasuk baik.

\section{Mikroenkapsulasi dan karakterisasi minyak asiri}

Tujuan utama mikroenkapsulasi adalah untuk melindungi bahan inti dari kondisi lingkungan yang merugikan, seperti efek cahaya, kelembaban, dan sehingga berkontribusi pada peningkatan umur simpan produk, dan mempromosikan pembebasan terkontrol enkapsulasi. ${ }^{19}$ Penggunaan gabungan alginat dan gelatin menghasilkan mikrokapsul yang sangat baik karena sedikitnya agregasi, ukuran partikel kecil, dan mudah terdispersi. ${ }^{20}$

Hasil karakterisasi mikrokapsul yang diperoleh tercantum pada Tabel 2. Penentuan persen kandungan minyak (\%OC) dalam mikrokapsul yang dihasilkan dan efisiensi enkapsulasi (\%EE) distandarisasi pada kurva baku minyak asiri jeruk nipis dengan menggunakan instrumen UV-Vis.

Tabel 2. Hasil karakterisasi

\begin{tabular}{lc}
\hline Parameter & Hasil \\
\hline Rendemen (\%) & $46,28 \%$ \\
Kandungan minyak (\%) & $61,89 \%$ \\
Efisiensi Enkapsulasi (\%) & $87,37 \%$ \\
\hline
\end{tabular}

Pada metode koaservasi kompleks, sifat material seperti bahan penyalut dan juga bahan inti kapsul, viskositas, tipe pelarut, dan penambahan zat aditif yang termasuk ke dalam parameter formulasi dapat mempengaruhi parameter \%OC dan \%EE. Selain itu kondisi pembuatan seperti suhu, $\mathrm{pH}$, dan laju pengadukan juga menjadi kesuksesan dari mikroenkapsulasi. ${ }^{21}$

Grafik hasil pengukuran ukuran dan distribusi partikel dengan PSA ditunjukkan pada Gambar 1.

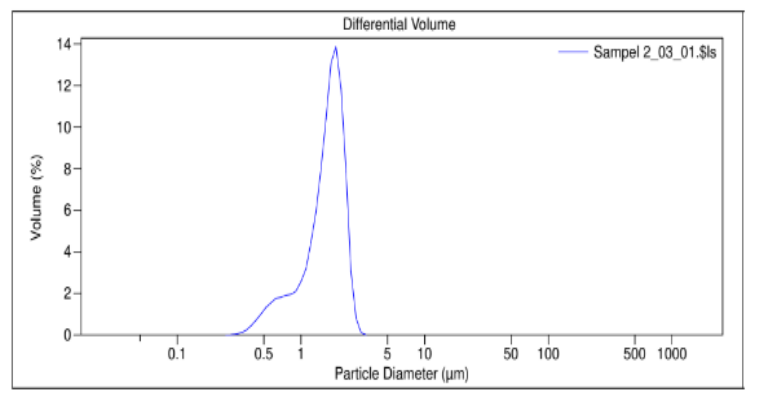

Gambar 1. Spektrum PSA mikrokapsul

Partikel sudah termasuk pada ukuran mikrokapsul dengan rata-rata ukuran partikel 1,604 $\mu \mathrm{m}$. Distribusi ukuran partikel homogen ditandai dengan munculnya satu puncak dominan yang tinggi dan lancip, dengan nilai rasio mean/median sebesar 0,951. Pelepasan minyak asiri dari mikrokapsul ditunjukkan pada Gambar 2.

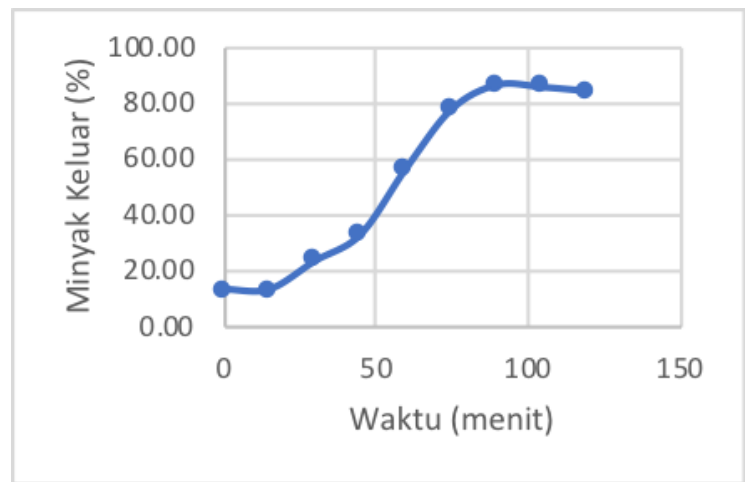

Gambar 2. Pelepasan minyak asiri dalam mikrokapsul

Pengukuran minyak asiri yang dilepas dari mikrokapsul dilakukan dengan pengadukan pada 100 rpm, dimaksudkan untuk merangsang pelepasan minyak asiri. Dari grafik pada Gambar 2 terlihat minyak asiri dilepas secara bertahap. Pengamatan tanpa rangsangan pengadukan telah dilakukan namun sampai waktu pengamatan larutan yang diukur tidak menunjukkan serapan pada UV. Hal ini membuktikan bahwa minyak asiri telah terlindungi dengan baik dalam mikrokapsul.

Mikrograf mikrokapsul dengan pembesaran 1000x terlihat pada Gambar 3, morfologi mikrokapsul berbentuk bulat dengan permukaan yang halus.

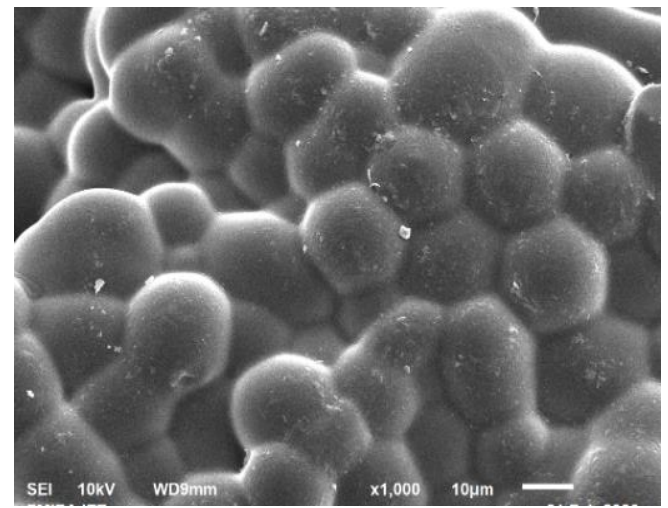

Gambar 3. Mikrograf SEM pada perbesaran 1000× 


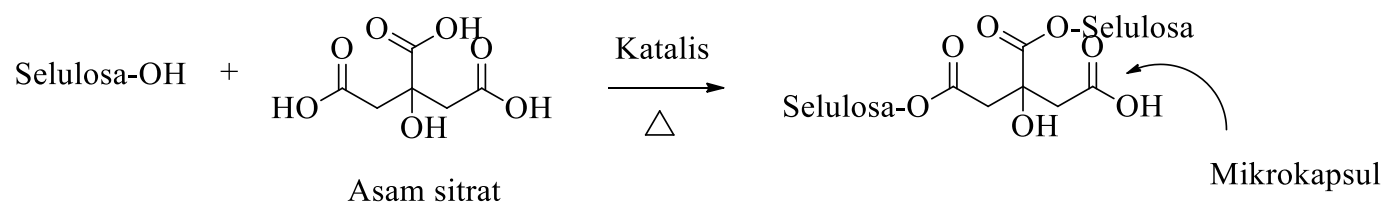

Gambar 4. Reaksi antara kain kapas, asam sitrat, dan mikrokapsul..$^{25}$

$$
\text { Selulosa-OH }+ \text { HO-Alg-COOH }+ \text { Asam sitrat } \stackrel{\text { Katalis }}{\longrightarrow} \begin{aligned}
& \mathrm{H}_{2} \mathrm{C}-\mathrm{COO} \text { selulosa } \\
& \mathrm{OH}-\mathrm{C}-\mathrm{COOH} \\
& \mathrm{H}_{2} \mathrm{C}-\mathrm{COOAlg} \cdot \mathrm{COOH}
\end{aligned}
$$

Alginat

Sampel kain yang disisipkan alginat

Gambar 5. Reaksi antara alginat dengan kain kapas menggunakan binder asam sitrat. ${ }^{26}$

\section{Imobilisasi mikrokapsul}

Imobilisasi mikrokapsul dilakukan pada kain kapas karena selain memiliki sifat yang sangat nyaman juga kemampuannya untuk mempertahankan kelembaban dan dapat menyerap keringat. ${ }^{22}$ Bahan yang berasal dari selulosa memiliki banyak keuntungan seperti biokompatibilitas, toksisitas rendah, kelarutan dalam air, dan biodegradabel. ${ }^{23}$ Asam sitrat digunakan karena merupakan bahan alami yang ramah lingkungan dan tidak beracun. Asam sitrat merupakan asam polikarboksilat, ${ }^{24}$ dan dapat bereaksi dengan kain kapas melalui reaksi esterifikasi. Gugus karboksilat dari asam sitrat akan bereaksi dengan gugus -OH dari selulosa kain kapas, seperti ditunjukkan pada Gambar $4^{25}$ dan Gambar 5. ${ }^{26}$

Untuk mengevalusi keberhasilan proses imobilisasi maka dilakukan pengukuran \% add on, yaitu persentase penambahan massa pada kain yang diimobilisasi setelah dikurangi massa kain sebelum diimobilisasi. Hasilnya seperti ditunjukkan pada Tabel 3.

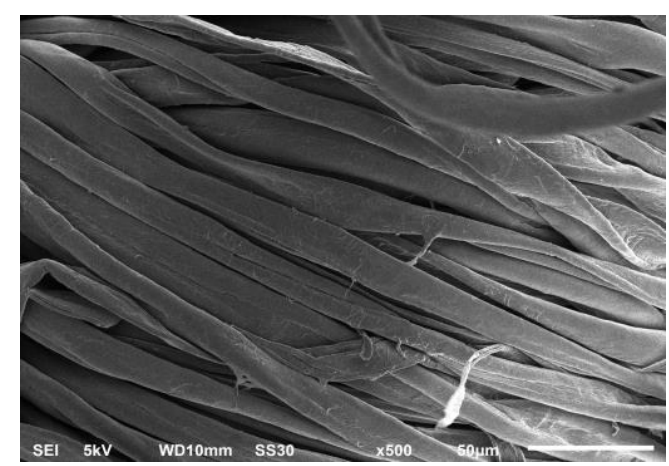

Gambar 6. Monograf SEM kain pada perbesaran 500× a) Kain sebelum diimobilisasi b) Kain setelah diimobilisasi

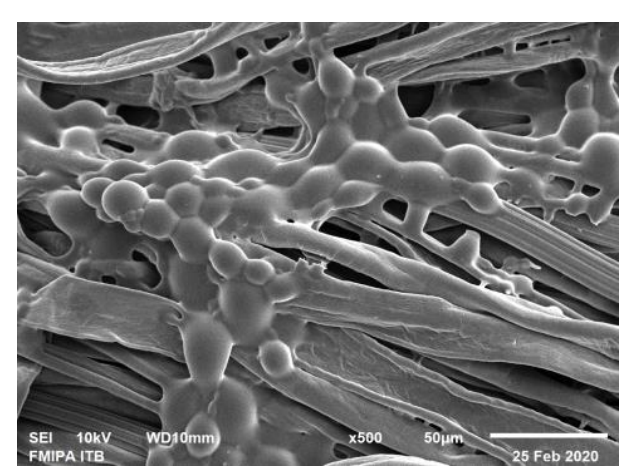

Tabel 3. Penambahan massa pada kain setelah imobilisasi

\begin{tabular}{lc}
\hline Massa kain & Massa (g) \\
\hline Sebelum diimobilisasi & 15,1784 \\
Setelah diimobilisasi & 16,2435 \\
Massa mikrokapsul yang & 1,0651 \\
terikat kain & \\
\hline
\end{tabular}

Dari data tersebut terlihat adanya penambahan massa pada kain setelah imobilisasi dengan $\%$ add on sebesar 7,02\%, hal ini membuktikan bahwa mikrokapsul telah berhasil terikat pada serat kain. Untuk lebih meyakinkan mikrokapsul telah terikat pada kain dilakukan pengukuran morfologi kain dengan SEM, monograf SEM ditunjukkan pada Gambar 6.

Dari Gambar 6 tersebut terlihat perbedaan yang jelas antara morfologi sebelum dan setelah imobilisasi, pada Gambar 6b tampak mikrokapsul telah terikat pada kain. 
Ketahanan cuci yang buruk merupakan salah satu kekurangan dari modifikasi kain kapas setelah dilakukan treatment. ${ }^{27}$ Untuk mengetahui karakter kain tersebut, dilakukan pengujian ketahanan cuci menggunakan instrumen launder-O-meter. Bahan tekstil dapat diukur ketahanan cucinya setara dengan beberapa kali pencucian rumah tangga. Pada penelitian ini, kain yang telah diimobilisasi diuji ketahanan cucinya setara dengan 1, 5, 10, dan 15 kali pencucian rumah tangga, kain yang digunakan untuk uji tersebut yaitu kain berukuran $4 \times 10 \mathrm{~cm}$ dan diujikan secara bersamaan. Hasilnya tercantum pada Gambar 7.

Dari Gambar 7 terlihat adanya penurunan massa selama pencucian, hal ini membuktikan minyak asiri/mikrokapsul telah dilepas. Penurunan massa tertinggi terjadi pada pencucian $5 \mathrm{x}$ yaitu sebesar 4,5\%, pada pencucian berikutnya penurunan massa berkurang. Hal ini dapat disebabkan karena mikrokapsul yang terlepas pada siklus pencucian awal umumnya merupakan mikrokapsul yang berukuran besar, sedangkan mikrokaspul berukuran kecil lebih bertahan pada kain. $^{28}$ Pelepasan minyak asiri terjadi secara bertahap, hal ini menandakan mikrokapsul terikat kuat pada kain sehingga perlakukan pencucian tidak dengan mudah melepas mikrokapsul yang sudah terikat.

Pengamatan morfologi kain setelah pencucian dengan SEM, ditunjukkan pada Gambar 8. Dari Mikrograf Gambar 8a pada saat pencucian 1x terlihat mikrokapsul masih banyak yang menempel pada kain dan pada pencucian berikutnya yaitu setara dengan $5 x, 10 x$, dan $15 x$ skala rumah tangga, jumlah mikrokapsul yang menempel semakin berkurang.

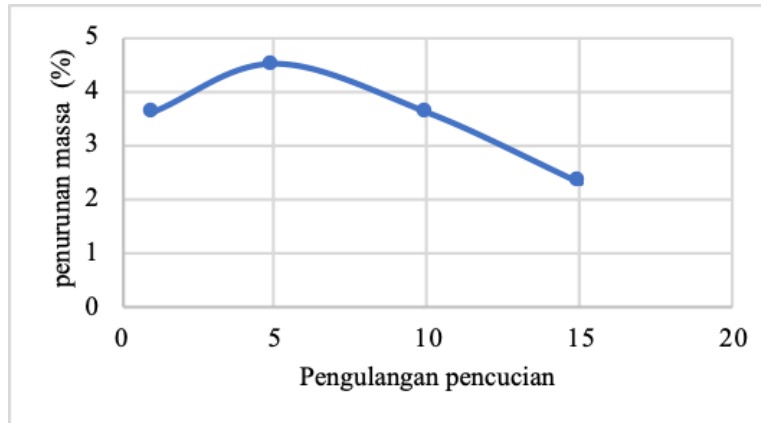

Gambar 7. Penurunan massa kain setelah pencucian
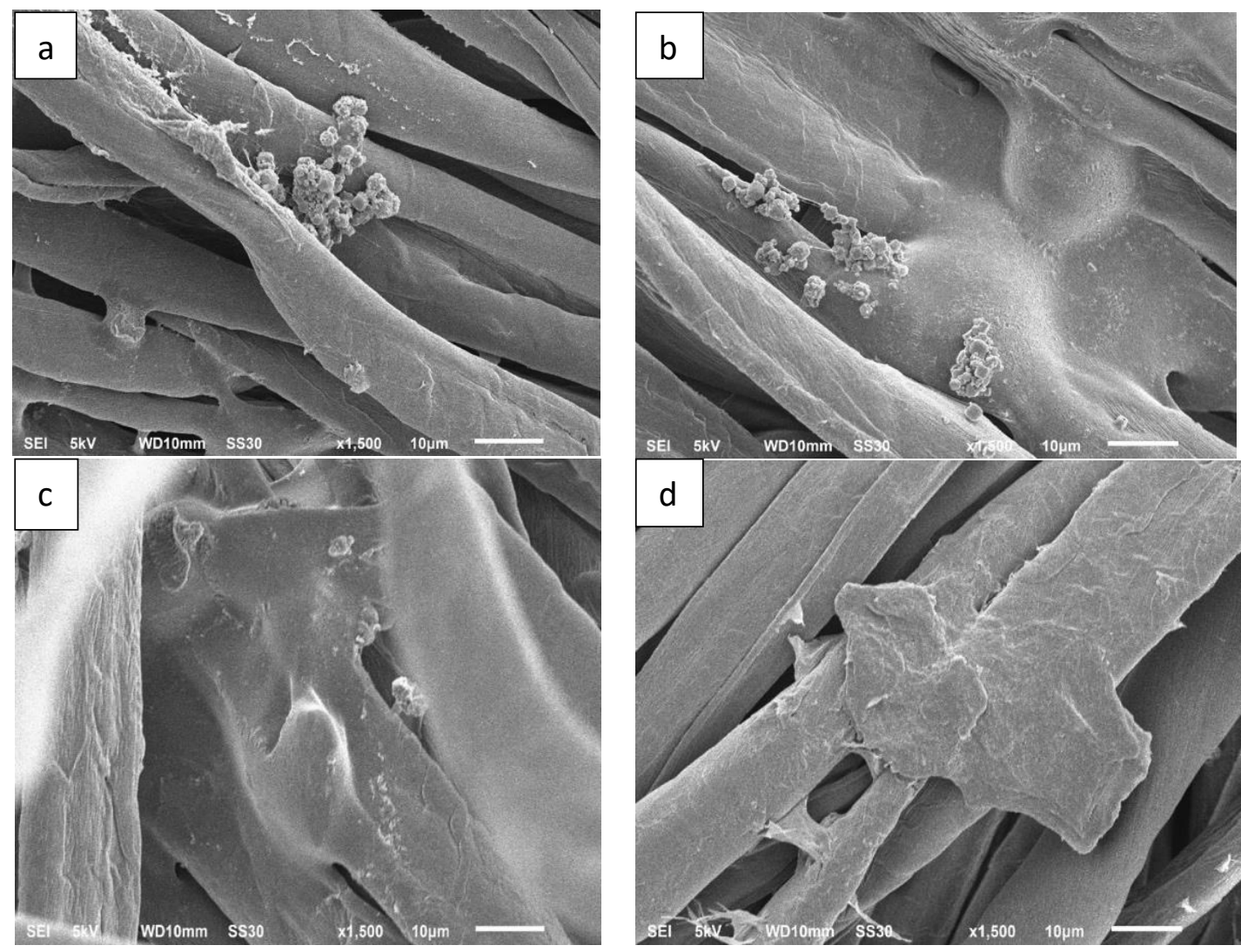

Gambar 8. Mikrograf SEM pada perbesaran $1500 \times$ pada kain setelah pencucian a) $1 \times$, b) $5 \times$, c) $10 \times$, dan d) $15 \times$ 
Tabel 4. Zona hambat pertumbuhan bakteri

\begin{tabular}{lcccc}
\hline \multirow{2}{*}{ Sampel } & \multicolumn{4}{c}{ Zona hambat (mm) } \\
\cline { 2 - 5 } & \multicolumn{2}{c}{ Bakteri Gram Positif } & \multicolumn{2}{c}{ Bakteri Gram Negatif } \\
\cline { 2 - 5 } & S. aureus & S. epidermidis & E. coli & K. pneumoniae \\
\hline Kain diimobilisasi mikrokapsul & $12,08 \pm 0,13$ & $8,90 \pm 0,10$ & $10,83 \pm 0,43$ & $10,40 \pm 0,10$ \\
Kain tanpa imobilisasi mikrokapsul & N.a & N.a & N.a & N.a \\
Minyak asiri jeruk nipis & $34,25 \pm 0,25$ & $37,60 \pm 0,00$ & $11,90 \pm 0,10$ & $36,68 \pm 2,33$ \\
Limonen & $24,40 \pm 0,10$ & $31,95 \pm 0,40$ & $27,88 \pm 0,43$ & $35,88 \pm 0,42$ \\
Kontrol Positif Ampisilin $(1000 \mathrm{ppm})$ & $35,58 \pm 0,57$ & $14,95 \pm 0,35$ & $10,55 \pm 0,55$ & $10,65 \pm 0,35$ \\
Kontrol Negatif $n$ - heksana & N.a & N.a & $8,10 \pm 0,40$ & N.a \\
\hline
\end{tabular}

\section{Aktivitas antibakteri}

Aktivitas antibakteri diujikan pada bakteri patogen yang hidup di permukaan kulit manusia seperti S. aureus, E. coli, K. pneumoniae, dan S. epidermidis. Selain pada kain yang telah diimobilisasi, pengujian dilakukan juga pada mikrokapsul, minyak asiri utuh, limonen autentik (komponen utama jeruk nipis), kontrol positif amplisilin, dan kontrol negatif pelarut $n$-heksana, dengan tujuan untuk membandingkan aktivitas di antara sampel-sampel tersebut. Hasilnya tercantum pada Tabel 4.

Berdasarkan level aktivitas Zone of Inhibition (ZoI) diklasifikasikan ke dalam empat kategori yaitu dengan diameter ZOI:> $20 \mathrm{~mm}$ sangat kuat; 10-20 mm kuat; 5-10 mm sedang; dan $<5 \mathrm{~mm}$ tidak ada respon. ${ }^{29}$ Dari Tabel 4 terlihat minyak asiri memiliki aktivitas yang sangat kuat terhadap ketiga bakteri S. aureus, S. epidermidis, dan $K$. pneumoniae melebihi kontrol positif dan limonen, serata kuat terhadap bakteri E. coli aktivitasnya sedikit lebih tinggi daripada kontrol positif, sedangkan dengan limonen aktivitas minyak asiri lebih rendah. Konstituen mayor dari minyak asiri jeruk nipis yang diketahui memiliki efek terhadap antimikrobial adalah limonen, $\alpha$ terpineol, dan $\mathbb{\gamma}$-terpinen. Menurut Nazzaro et al., ${ }^{30}$ aktivitas antimikroba senyawa limonen dan simen disebabkan oleh keberadaan gugus alkil. Terpen hidrokarbon siklik seperti $\alpha$-pinen bersama dengan $\beta$-pinen, limonen, dan terpineol dilaporkan memberikan efek toksik pada mikroorganisme. ${ }^{31}$

Aktivitas antimikrobial oleh minyak asiri dikarenakan keberadaan terpenoid. Fase berair digantikan oleh terpenoid sehingga menyebabkan ekspansi membran, meningkatnya fluiditas dan permeabilitas, gangguan protein, penghambatan pernapasan, juga pengubahan proses transportasi ion. ${ }^{31}$ Minyak asiri yang bersifat lipofilik dapat berinteraksi dengan mengubah permeabilitas membran sel dalam mikroorganisme. Karakter lipofilik tersebut mengakumulasikan lipid pada dinding sel, sehingga dapat menyebabkan protein terdenaturasi dan kehilangan integritas membran, lalu akan mengarahkannya kepada kebocoran sitoplasma dan akhirnya mati. ${ }^{31}$
Secara umum dapat dinyatakan bahwa adanya kerja sinergis antara komponen-komponen yang terdapat pada minyak asiri jeruk nipis. Kain yang tidak diimobilisasi tidak terdeteksi menunjukkan adanya aktivitas pada semua bakteri uji. Kain yang telah diimobilisasi menunjukkan aktivitas namun aktivitasnya lebih rendah daripada aktivtas minyak asirinya. Hal ini dapat terjadi karena pertama jumlah minyak asiri yang terdapat dalam kain tersebut tidak diketahui dengan tepat, kedua minyak asiri dalam kain baru sedikit yang dilepas. Hal ini seperti yang diharapkan bahwa minyak asiri dilepas tidak sekaligus namun secara bertahap.

\section{KESIMPULAN}

Hasil karakterisasi mikrokapsul diperoleh rendemen $46,28 \%$, kandungan minyak $61,89 \%$, EE $87,37 \%$, dengan morfologi berbentuk bulat dan halus, distribusi ukuran yang homogen dengan ukuran rata-rata $1.604 \mu \mathrm{m}$. Mikrokapsul terikat pada kain kapas dengan baik, kain memiliki ketahanan cuci yang baik. Kain dapat menghambat pertumbuhan bakteri dengan aktivitas sedang. Aktivitas minyak asiri jeruk nipis sangat kuat pada semua bakteri dan aktivitasnya lebih tinggi daripada limonen. Adanya kerja sinergis antara komponen-komponen yang terdapat pada minyak asiri jeruk nipis.

\section{UCAPAN TERIMA KASIH}

Penulis mengucapkan terima kasih kepada Kementerian Riset, Teknologi, dan Pendidikan Tinggi atas dukungan pendanaan Penelitian Dasar Unggulan Perguruan Tinggi tahun anggaran 2020 dengan No kontrak 1827/UN6.3.1/LT/2020 dan kepada Balai Besar Tekstil atas kerjasama penelitian dan fasilitas yang diberikan.

\section{PUSTAKA}

1. Enejoh, O.S., Ogunyemi, I.O., Bala, M.S., Oruene, I.S., Suleiman, M.M., \& Ambali, S.F. Ethnomedical Importance of Citrus aurantifolia (Christm) Swingle. The Pharma Innovation Journal, 4 (9), 01-06 (2015).

2. Elshafie, H.S. \& Camele, I. An Overview of the Biological Effects of Some Mediterranean 
Essential Oils on Human Health. BioMed Research International, 1-14 (2017).

3. Firenzuoli, F., Jaitak, V., Horvath, G., Bassolé, I.H.N., Setzer, W.N., \& Gori, L. Essential Oils: New Perspectives in Human Health and Wellness. Evidence-Based Complementary and Alternative Medicine: 1-2 (2014).

4. Lin, L.Y., Chuang, C.H., Chen, H.C., \& Yang, K.M. Lime (Citrus aurantifolia (Christm.) Swingle) Essential Oils: Volatile Compounds, Antioxidant Capacity, and Hypolipidemic Effect. Foods, 8, 398 (2019).

5. Burt, S. Essential oils: their antibacterial properties and potential applications in foods: a review. 94, 223-253 (2004).

6. Wahyudi, T., Mulyawan, A.S., Kasipah, C., Prayudie, U., Julaeha, E., Pembuatan Mikrokapsul Minyak Jeruk (Citrus Aurantifolia) Untuk Aplikasi Pada Penyempurnaan Tekstil, Arena Tekstil. 32 (1), 1-8 (2017).

7. Chanthaphon, S., Chanthachum, S., \& Hongpattarakere, T. Antimicrobial activities of essential oils and crude extracts from tropical Citrus spp. against food-related microorganisms. 30, 125-131 (2008).

8. Al-Aamri M.S., Al-Abousi, N.M., Al-Jabri, S.S., Alam, T., \& Khan, S.A. Chemical Composition and In-vitro Antioxidant and Antimicrobial Activity of The Essential Oil of Citrus aurantifolia L. Leaves Grown in Eastern Oman. Journal of Taibah University Medical Sciences, 13 (2): 108-112 (2018).

9. Mahato, N., Sharma, K., Koteswararao, R., Sinha, M., EkRaj Baral, E., \& Cho, MH. Citrus Essential Oils: Extraction, Authentication and Application in Food Preservation. Critical Reviews in Food Science and Nutrition. Taylor \& Francis, 59 (4), 611-625 (2017).

10. Julaeha, E., Nugeraha, R., Nurzaman, M., Kurnia, D., Wahyudi, T., \& Rosandi, Y. Characterization of Ethyl Cellulose (EC) Microcapsules for Lime Oil Encapsulation. Journal of Physics: Conference Series, 1080: 1-5 (2018).

11. Adamiec, J., Borompichaichartkul, C., Srzednicki, G., Panket, W., Piriyapunsakul, S., $\&$ and Zhao, J. Microencapsulation of Kaffir Lime Oil and Its Functional Properties. Drying Technology, 30, 914-920 (2012).
12. Kumari, P., Rose, N.M., \& Singh, S.S.J. Microencapsulation of lime essential oil for fragrant textiles. Annals of Agri Bio Research, 20 (1), 152-157 (2015).

13. Sharkawy, A., Fernandes, I. P., Barreiro, M. F., Rodrigues, A. E., \& Shoeib, T. AromaLoaded Microcapsules with Antibacterial Activity for EcoFriendly Textile Application: Synthesis, Characterization, Release, and Green Grafting. Industrial and Engineering Chemistry Research, 56, 5516-5526. (2017).

14. Wijesirigunawardana, P.B. \& Perera, B.G.K. Development of a Cotton Smart Textile with Medicinal Properties Using Lime Oil Microcapsules. Acta Chim. Slov, 65, 150-159 (2018).

15. Puspita, S., Eddy, D.R., Wahyudi, $\mathrm{T}$ \& Julaeha, E. Microencapsulation of Lime Peel Essential Oils (Citrus aurantifolia) with Complex Coacervation Methods using Gelatin/Sodium Alginate Coating. Jurnal Kimia, 6 (1), 106-112 (2020).

16. Devi, N., Hazarika, D., Deka, C., \& Kakati, D.K. Study of Complex Coacervation of Gelatin A and Sodium Alginate for Microencapsulation of Olive Oil. Journal of Macromolecular Science, Part A: Pure and Applied Chemistry, 49, 936-945 (2012).

17. Molide, R., Rusli, M.., \& Mulyadi, A. Minyak Asiri Indonesia. Bogor: IPB (2009).

18. Preedy, V.R. Essential Oils in Food Preservation, Flavor and Safety. Elsevier. London (2016).

19. Fang, Z. \& Bhandari, B. Encapsulation of polyphenols - A review. Trends in Food Science and Technology. 21 (10), 510-523 (2010).

20. Xiao, Z., Liu, W., Zhu, G., Zhou, R., \& Niu, Y. Review of The Preparation and Application of Flavour and Essential Oils Microcapsules Based on Complex Coacervation Technology. Journal of the Science of Food and Agriculture. 94, 1482-1494 (2014).

21. Paulo F. dan Santos, L. Design of Experiments for Microencapsulation Applications: A Review. Materials science and engineering. 33, 1327-1340 (2017).

22. Khodary, M.M.M., El-Rafie, H.M., Abdel Salam, H.M., \& El-Rafie, M.H. Imparting Eco-friendly Antibacterial and Antiinflammatory Finishing by Microencapsulation Technique for Cotton 
Mikroenkapsulasi Minyak Asiri Jeruk Nipis dengan Koaservasi Kompleks yang Beraktivitas Antibakteri untuk Aplikasi pada Bahan Tekstil (Euis Julaeha, dkk.)

Fabric. International Design Journal, 7 (2), 131-140 (2017).

23. Singh, S., \& Dutt, D. Cotton pulp for bone tissue engineering. Journal of Biomaterials Science, Polymer Edition, 1-14 (2020).

24. Fouda, M.M.G., \& Fahmy, H.M. Multifunctional finish and cotton cellulose fabric. Carbohydrate Polymer, 86 (2), 625629 (2011).

25. Zanrosso, C.D. dan Lansarin, M.A. Application of Polycarboxylic Acids as Binders for $\mathrm{TiO}_{2}$ Immobilization on Cotton Textiles. Brazilian Journal of Chemical Engineering. 36 (01), 181 - 190 (2019).

26. Ibrahim, N.A., Eid, B.M., Abd El-Ghany, N.A., \& Mabrouk, E.M.. Polyfunctional cotton cellulose fabric using proper biopolymers and active ingredients. The Journal of The Textile Institute. 111 (3), 381393 (2019).

27. Zhang, T., Luo, Y., Wang, M., Chen, F., Liu, J., Meng, K., \& Zhao, H. Double-Layered
Microcapsules Significantly Improve the Long-Term Effectiveness of Essential Oil. Polymers, 12, 1651 (2020).

28. Monllor, P., Capablanca, L., Gisbert, J., Díaz, P., Montava, I., \& Bonet, A. Improvement of Microcapsule Adhesion to Fabrics. Textile Research Journal, 80 (7), 631-635 (2010).

29. David, W.W. \& Stout, T.R. Disc plate method of microbiological antibiotic assay. I. Factors influencing variability and error. Appl. Microbiol, 22, 659-665 (1971).

30. Nazzaro, F., Fratianni, F., Martino, L., Coppola, L., dan Feo, V. Effect of Essential Oils on Pathogenic Bacteria. Pharmaceuticals. 6, 1451-1474 (2013).

31. Jafari, S., Eshafani, S., Fazeli, M.R., Jamalifar, H., Samadi, M., Samadi, N., Najarian Toosi, A., Shams Ardekani, M.R., dan Khanavi, M. Antimicrobial activity of lime essential oil against food-borne pathogen isolated from cream-filled cakes and pastries. International Journal of Biological Chemistry. 5 (4), 258 (2011). 
Arena Tekstil Vol. 35 No. 2, 2020 : 67-76 